\title{
Autophagy induction causes a synthetic lethal sensitization to ribonucleotide reductase inhibition in breast cancer cells
}

\author{
Yun-Ru Chen ${ }^{1,2}$, Brittany Tsou ${ }^{1,2}$, Shuya Hu${ }^{1}$, Huimin Ma ${ }^{1,2}$, Xiyong Liu ${ }^{1}$, Yun Yen ${ }^{1}$ \\ and David K. Ann ${ }^{1,2}$ \\ ${ }^{1}$ Department of Molecular Pharmacology, Beckman Research Institute, City of Hope National Medical Center, Duarte, CA, \\ USA \\ 2 Department of Diabetes and Metabolic Research, Beckman Research Institute, City of Hope National Medical Center, \\ Duarte, CA, USA \\ Correspondence to: Yun Yen, email: y.yenmd@gmail.com
}

David K. Ann, email: dann@coh.org

Keywords: autophagy, ribonucleotide reductase, synthetic lethality, breast cancer, tamoxifen

Received: June 22, $2015 \quad$ Accepted: November 21, $2015 \quad$ Published: December 09, 2015

\section{ABSTRACT}

Macroautophagy can promote cellular survival or death depending on the cellular context and its extent. We hypothesized that autophagy induction would synergize with a therapeutic agent targeting the autophagic cargo. To test this hypothesis, we treated breast cancer MDA-MB-231 cells with tamoxifen (TMX), which induces autophagy through an estrogen receptor-independent pathway. Induction of autophagy reduced cellular levels of RRM2, a subunit of ribonucleotide reductase (RR), the rate limiting enzyme in the production of deoxyribonucleotide triphosphates (dNTPs). This autophagy inducer was combined with COH29, an inhibitor developed in our laboratory that targets RR through a novel mechanism. The combination therapy showed synergistic effects on cytotoxicity in vitro and in an in vivo xenograft model. This cytotoxicity was blocked by knockdown of the autophagy protein ATG5 or addition of chloroquine, an autophagy inhibitor. The combined therapy also induced dNTP depletion and massive genomic instability, leading us to hypothesize that combining autophagy induction with RR inhibition can lead to mitotic catastrophe in rapidly dividing cells. We propose that this TMX + COH29 combined therapy may have clinical benefit. Furthermore, autophagy induction may be a general mechanism for augmenting the effects of chemotherapeutic agents

\section{INTRODUCTION}

Cell death is an important process in cancer therapy that occurs through three major pathways: apoptosis, autophagy, and necrosis - each of which can be characterized by various morphological criteria [1]. First, apoptosis is a form of programmed cell death that involves cell rounding, DNA fragmentation, and cell membrane blebbing. Subsequent engulfment of apoptotic cells by phagocytes prevents an inflammatory response to the dead cells. Second, autophagy is a self-degradative pathway for disposal of obsolete parts of the cell, is accompanied by vacuolization in the cytoplasm and can lead to increased cell survival or cell death depending on the type and extent of self-degradation [2]. During autophagy, organelles and parts of the cytoplasm are isolated in characteristic double-membrane organelles known as autophagosomes. Fusion of the autophagosomes with lysosomes can allow for degradation and recycling as part of the quality control process that maintains bioenergetics and basic cell functions [3, 4]. However, we and others have also shown that prolonged starvation of arginine induces oxidative stress and triggers autophagic cancer cell death $[5,6]$. Third, necrosis is defined as a type of cell death that lacks features of the two previous pathways and is accompanied by swelling of the cell, loss of membrane integrity, and inflammatory response, as the cellular contents are released into the extracellular environment [1]. Cell death pathways play important roles in tumorigenesis, cancer progression, and resistance to therapy and thus are important therapeutic targets in cancer [7].

One therapeutic approach is to induce an imbalance of critical cellular components, leading to reduced proliferation and death of the cancer cells. For instance, deoxyribonucleotide triphosphates (dNTP) are required building blocks for cells to carry out the basic functions of DNA synthesis and repair. Thus, imbalanced levels of dNTPs result in mutagenesis, genomic instability and cell death [8]. The intracellular supply of dNTPs is regulated by ribonucleotide reductase (RR), an enzyme that catalyzes the formation of deoxyribonucleotides from 
ribonucleotides, and plays a critical role in regulating the total rate of DNA synthesis [9]. RR is also one of the top 50 metabolic enzymes frequently overexpressed in human tumors [10]. As a result, RR is a popular target for anticancer agents such as RR inhibitors [11]. RR consists of two protein subunits, RRM1 and RRM2, both of which are required for enzymatic activity. Two RRM1 subunits and two RRM2 subunits join together to form the active tetrameric enzyme. RRM1 and RRM2 are encoded by different genes on separate chromosomes and, most importantly, their messenger RNAs (mRNAs) are differentially expressed throughout the cell cycle. The cellular RRM1 protein level remains relatively stable through the entire cell cycle and has a relatively long halflife of 18 to $24 \mathrm{~h}$. In contrast, RRM2 is only expressed during the late $\mathrm{G}_{1}$-/early S-phase when DNA replication occurs, has a short half-life of 3 to $4 \mathrm{~h}$, and is rapidly degraded in late mitosis. Therefore, RR enzyme activity is largely determined by the RRM2 protein levels in normal cells.

We have identified a novel small molecule RR inhibitor, $\mathrm{COH} 29$ that disrupts the interactions between the hRRM1 and RRM2 subunits of human RR [12]. $\mathrm{COH} 29$ is an aromatically substituted thiazole compound [N-(4-(3,4-dihyrophenyl)-5-phenylthiazol-2-yl)

-3,4-dihydroxybenzamide], which we developed from a virtual screen of the National Cancer Institute (NCI) Diversity Set with 2000 compounds (NCI2000). We screened for the ability to bind a pocket on the surface of the M2 subunit of RR, as predicted by protein structural analysis [12]. Candidate compounds identified from this screening were further optimized by iterative virtual and structure activity relationship (SAR) analysis to yield $\mathrm{COH} 29$. The aromatically substituted thiazole compound binds to RRM2 and occupies a ligand-binding pocket on hRRM2 that is positioned close to the hRRM1-hRRM2 interface. It thereby impedes formation of the holoenzyme complex and inhibits RR activity. Unlike other RR inhibitors, $\mathrm{COH} 29$ does not appear to chelate iron, so side effects are likely to be reduced. Through interference with DNA repair and replication pathways, $\mathrm{COH} 29$ upsets the balance of dNTP in cells, leading to cell death. Because $\mathrm{COH} 29$ has limited effects as a single therapeutic agent, we used various biochemical, cell biological, and xenograft approaches to find a combination therapy that reduced the toxicity and increased the efficacy of $\mathrm{COH} 29$.

Tamoxifen (TMX), a nonsteroidal estrogen-receptor $\alpha(E R \alpha)$ modulator, is a widely used therapeutic agent for patients with ER $\alpha$-positive breast cancers $[13,14]$. TMX primarily functions by competing with estrogen for binding to $\mathrm{ER} \alpha$, thereby inhibiting $\mathrm{ER} \alpha$ activity [15]. As a result, TMX is primarily used to reduce the recurrence of ER $\alpha$-positive breast tumors [16]. However, results from both pre-clinical and clinical investigations have demonstrated a beneficial effect of TMX on ER $\alpha$ negative tumors or cancer cells [13, 17-21], suggesting that TMX can also act in an ER $\alpha$-independent manner. Along the same lines, in vitro studies have suggested that TMX, besides inducing apoptosis in tumor cells, also promotes the accumulation of large-scale autophagic structures. These findings indicate that TMX may induce cancer cell death through autophagy [22,23]. The role of autophagy in cancer cell death has been exploited by both pharmacological and genetic approaches that modulate autophagy [3, 24, 25]. Modulating autophagy requires extra caution because autophagy can protect cancer cells in the early stages of chemotherapy, but promote tumor cell death afterwards $[3,24,25]$. Furthermore, autophagy can be induced by various stimuli, including nutrient deprivation, serum starvation, metabolic stress, radiation, and anticancer drugs in multiple cancer cells [24, 26-29]. We propose to exploit autophagy-dependent cell death to promote the efficacy of $\mathrm{COH} 29$-based cancer therapies.

Our previous study has shown that the regulation of the dNTP pool and RRM2 levels are inversely related to levels of autophagy [30]. In that report, reduced RRM2 abundance was associated with, increased autophagy and a decreased intracellular dNTP pool. On the other hand, overexpression of RRM2 or supplementation of exogenous deoxyribonucleotide monophosphates (dNMPs) to increase the intracellular dNTP levels attenuated autophagy [30]. We hypothesized that adding an autophagy inducer may boost the effectiveness of COH29 by reducing the total levels of RRM2. Therefore, we evaluated the effects of combining TMX with $\mathrm{COH} 29$ in ER-negative MDA-MB-231 breast cancer cells both in vitro and in vivo. We found that combined use of TMX and COH29 reduced intracellular dNTP levels, induced genomic instability, promoted tumor cell death, and reduced tumor volume in a xenograft model. These effects were dependent on autophagy. The effects of the drug combination were far greater than the effects of either drug alone. This study proposes an effective antitumor regimen and, more broadly, establishes aggressive autophagy induction as a plausible method for increasing the sensitivity of cells to chemotherapy.

\section{RESULTS}

\section{Tamoxifen sensitizes breast cancer MDA-MB-231 cells to $\mathrm{COH} 29$ through autophagy induction}

Based on our previous work [30], we hypothesized that inducing autophagy would decrease RRM2 levels and sensitize cancer cells to $\mathrm{COH} 29$, a novel RR inhibitor $[12,31]$. Consequently, we combined TMX, an autophagy inducer, with $\mathrm{COH} 29$ in ER $\alpha$-negative (ER-) breast cancer cells and measured the resulting cytotoxicity $[32,33]$. We transfected the cells with green fluorescent protein (GFP) linked to the autophagosome marker microtubule 
associated protein 1A/1B light chain (LC3). TMX treatment induced autophagy in MDA-MB-231 cells (Figure 1A, left panel), as evidenced by the accumulation of GFP-LC3 puncta over time (Figure 1A, right panel). Addition of TMX $(10 \mu \mathrm{M})$ to the MDA-MB-231/GFPLC 3 cells caused a significant decrease in GFP intensity starting at $24 \mathrm{~h}$ post-treatment, whereas treatment with a lower concentration of TMX $(5 \mu \mathrm{M})$ needed up to 48 $\mathrm{h}$ to render a significant decrease (Figure 1B). These results suggested that TMX treatment induces autophagy in MDA-MB-231 cells in a concentration- and timedependent manner.

Western analyses were used to monitor the protein abundances of RRM2, LC3 and p62/SQSTM1, another autophagy marker, in breast cancer cells treated with TMX for 24 and $48 \mathrm{~h}$. Consistently, TMX decreased RRM2 abundance in several breast cancer cell lines including MDA-MB-231, MCF7 and T47D, regardless of their ER $\alpha$ status (Figure 1C and Supplementary Figure S1A). However, TMX had no effect on RRM2 abundance in autophagy-deficient ATG5-knockdown MDA-MB-231 (MDA-MB-231/shATG5) cells (Figure 1C). We also used western analysis to measure the autophagy-induced lipidation of LC3. As expected, LC3 lipidation increased (appearance of LC3-II) and p62/SQSTM1 abundance decreased in response to TMX, but accumulated in the presence of bafilomycin A1 (BafA1), a potent and selective inhibitor of vacuolar $\mathrm{H}^{+}$-ATPase (V-ATPase) that prevents the autophagic degradation via lysosomes $[34,35]$. This result further supports a model where TMX induces autophagy. The effect of BafA1 observed in MDA-MB-231/shATG5 was due to the incomplete knockdown of ATG5 (Figure 1C, right panel).

Next, we hypothesized that the TMX-induced, autophagy-mediated RRM2 downregulation sensitizes MDA-MB-231 cells to anti-RR agents, such as $\mathrm{COH} 29$. To test this possibility, MDA-MB-231 cells were maintained with the increasing concentrations of $\mathrm{COH} 29$-in the presence or absence of TMX for $72 \mathrm{~h}$. Cell viability was determined using acid phosphatase (ACP) assays at $72 \mathrm{~h}$ post-treatment (Figure 1D). As expected, the combination treatment was more effective at reducing cell viability than $\mathrm{COH} 29$ alone. The IC50 for $\mathrm{COH} 29$ is approximately $35 \mu \mathrm{M}$ and $17 \mu \mathrm{M}$ in the presence and absence of TMX, respectively (Figure 1D). We further confirmed that the combination treatment also resulted in autophagy induction by analyzing GFP-LC3 puncta formation (Figure 1E, upper panel). The combined treatment with $\mathrm{COH} 29$ did not affect the ability of TMX to induce autophagy (Figure 1E, lower panel). Moreover, TMX induced RRM2 reduction was also observed in the ER $\alpha$-positive breast cancer T47D and MCF7 cells (Supplementary Figure S1A), suggesting that it is not breast cancer subtype is specific. Along the same line, a dose-dependent cytotoxic effect by the combination of $\mathrm{COH} 29$ and TMX was also noted in T47D and MCF7 cells (Supplementary Figure S1B). However, the nontumorigenic mammary MCF-10A cells were less sensitive to the combined treatment (Supplementary Figure S1B). We have previously shown that rapamycin decreased RRM2 level in an autophagy-dependent manner in KB cells [30]. Here, we further demonstrated that rapamycin $(10 \mu \mathrm{M})$ also sensitized MDA-MB-231 cells to $\mathrm{COH} 29$ treatment by reducing RRM2 expression (Supplementary Figures S2A and S2B). The involvement of autophagy in promoting $\mathrm{COH} 29$ cytotoxicity was further examined in the context of arginine deprivation with arginine deiminase (ADI, $0.2 \mu \mathrm{g} / \mathrm{ml}$ ), known to induce rapamycinindependent autophagy [6], and comparable results were observed (Supplementary Figures S2C and S2D). Together, these results support a model where autophagy induction, through TMX, sensitizes cancer cells to $\mathrm{COH} 29$-induced cell death.

\section{The synergistic effects of $\mathrm{COH} 29$ + tamoxifen combination are autophagy-dependent}

To explore the mechanism underlying the improved efficacy of combining TMX with COH29, MDAMB-231 and MDA-MB-231/shATG5 cells were treated with the combination of $\mathrm{COH} 29$ and TMX. Figure 2A reveals that MDA-MB-231 cells were more sensitive to treatment than their isogenic autophagy-deficient (ATG5-knockdown) counterparts, suggesting that the combinatorial effect of TMX and $\mathrm{COH} 29$ was autophagydependent (Figure 2A). The viability data was further analyzed by Compusyn software to determine whether the drugs showed synergistic effects. The combination index (CI) for the combination in MDA-MB-231 was 0.18, indicating a synergistic effect, whereas the CI was 1.53 in MDA-MB-231/shATG5 cells, suggesting no evidence of synergy (Figure 2B). To further confirm the synergistic effect is autophagy-dependent, knockdown of BECLIN1 or ATG5, a key molecule for autophagy induction, also conferred a pro-survival effect, like in the context of combined treatment (Supplementary Figure S1C). Next we determined if the combined inhibitory effect was autophagy-dependent by using an autophagy inhibitor, chloroquine (CQ). The cells were treated with TMX and $\mathrm{COH} 29$, as indicated, in the presence and absence of CQ $(20 \mu \mathrm{M})$. The addition of CQ resulted in a significant rescue of cell viability in cells treated with 10 or $20 \mu \mathrm{M}$ each of TMX and COH29 (Figure 2C). Moreover, pretreatment with TMX for $24 \mathrm{~h}$ to induce autophagy notably enhanced the cytotoxicity induced by TMX and $\mathrm{COH} 29$ ( $20 \mu \mathrm{M}$ each). Consistently, the enhanced cytotoxic effect of sequential treatment was also retarded by $\mathrm{CQ}$ addition (Figure 2C).

Next, we tested the hypothesis that reduced RRM2 levels would deplete intracellular dNTP pools. We measured the dNTP pools in treated cells, and found that 
A

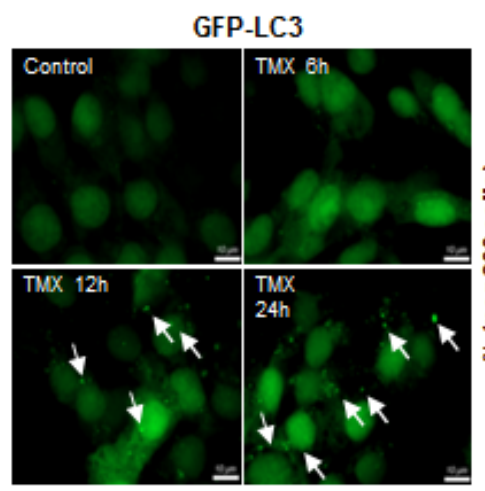

B

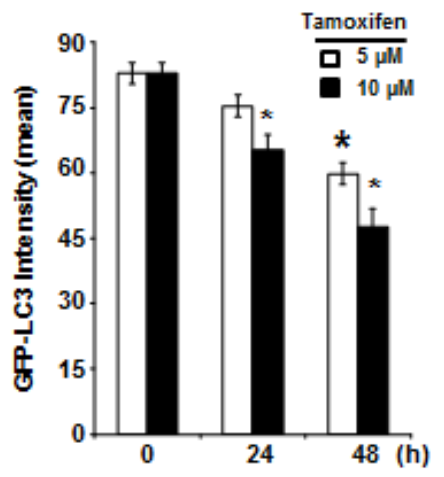

C
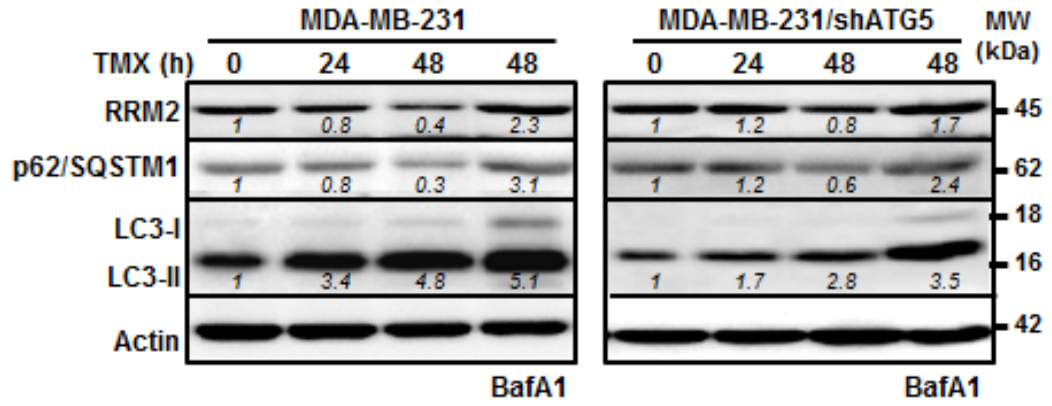

D

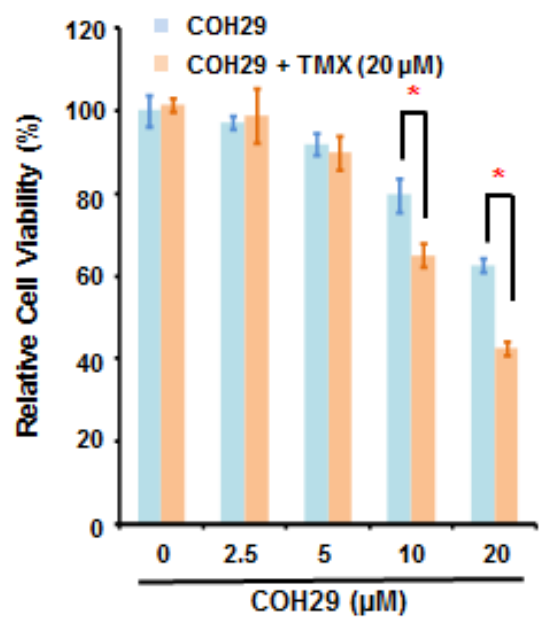

$\mathbf{E}$

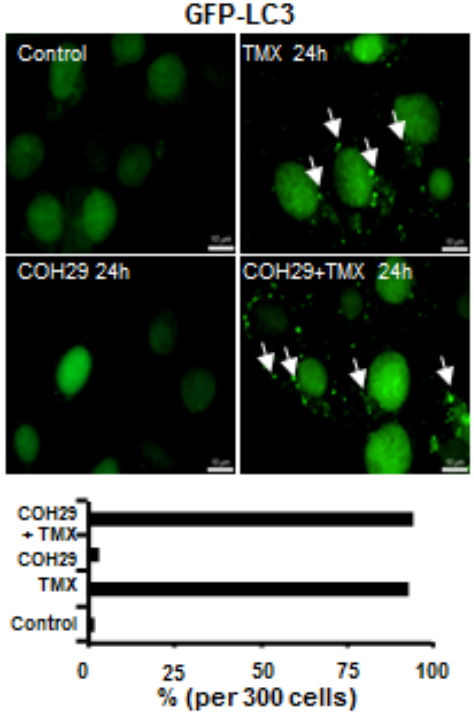

Figure 1: Tamoxifen enhances the cytotoxic effects of $\mathrm{COH} 29$ through autophagic degradation of RRM2. A. and $\mathrm{B}$. Tamoxifen (TMX) induces autophagy in MDA-MB-231 cells. MDA-MB-231 cells with stable integration of GFP-LC3 were treated with TMX $(5$ or $10 \mu \mathrm{M})$ for the indicated time periods and analyzed with microscopy A. and flow cytometry B.. A. Arrows indicate GFP-LC3 puncta. The percentage of cells containing GFP-LC3 puncta was enumerated by counting 300 cells and plotted (right panel). B. For flow cytometry, quantitation was showed in means $\pm \mathrm{SD}$ from three independent experiments; $;: p<0.05$ versus control. C. Knockdown of ATG5 stabilizes RRM2 in TMX-treated MDA-MB-231 cells. Western blotting was performed to determine RRM2 abundance, p62/SQSTM1 degradation, and LC3 lipidation (LC3-II) in autophagy-competent MDA-MB-231 and autophagy-impaired MDA-MB-231/shATG5 cells. Actin abundance was used as an internal control to ensure that equal amounts of proteins were loaded in each lane. Bafilomycin A1 (BafA1; $10 \mathrm{nM}$ ) was used to validate the lysosomal degradation. One representative Western from $n=3$ is shown. D. TMX sensitizes MDA-MB-231 cells to COH29. MDA-MB-231 cells were cultured with increasing concentrations of $\mathrm{COH} 29$ with and without $20 \mu \mathrm{M}$ TMX for indicated time periods prior to cytotoxicity assays. The means $\pm \mathrm{SD}$ from three independent experiments are shown;,$: p<0.05$ versus control. E. COH29 does not affect the induction of autophagy by TMX. Arrows indicate GFP-LC3 puncta. (A, D) Scale bar: $10 \mu \mathrm{m}$. 
A

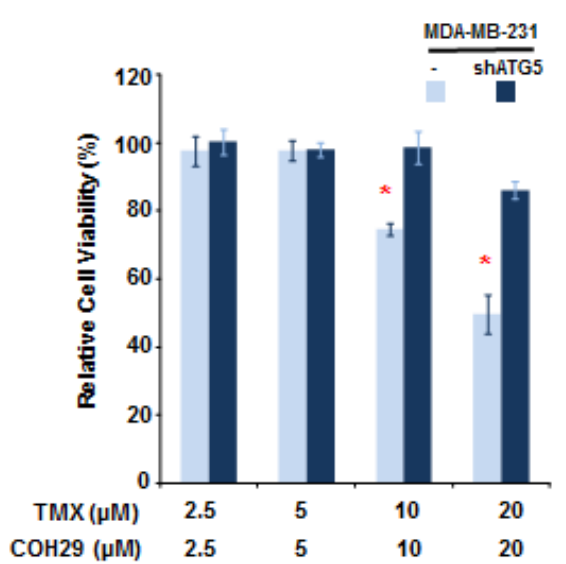

C

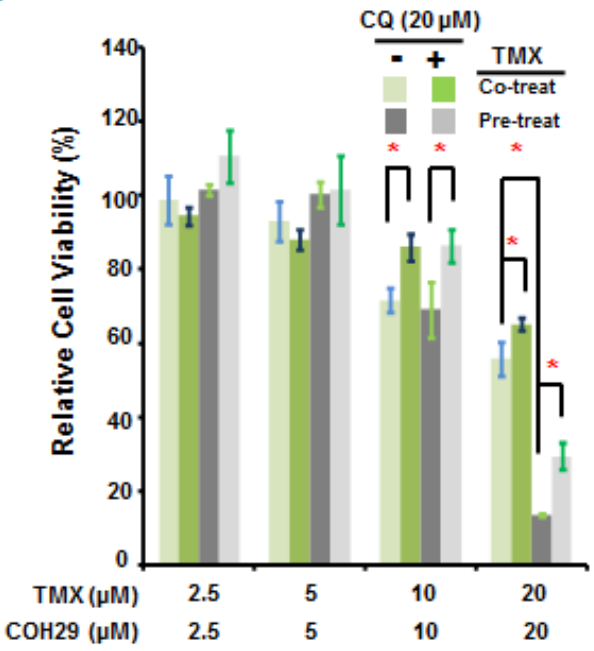

B

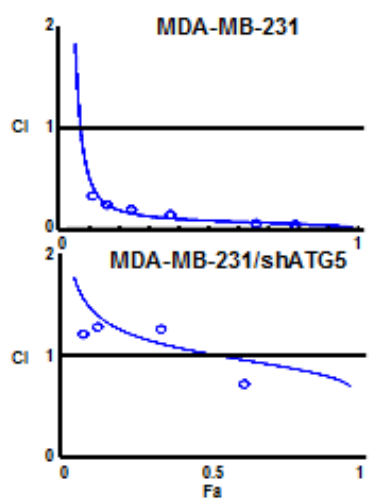

D

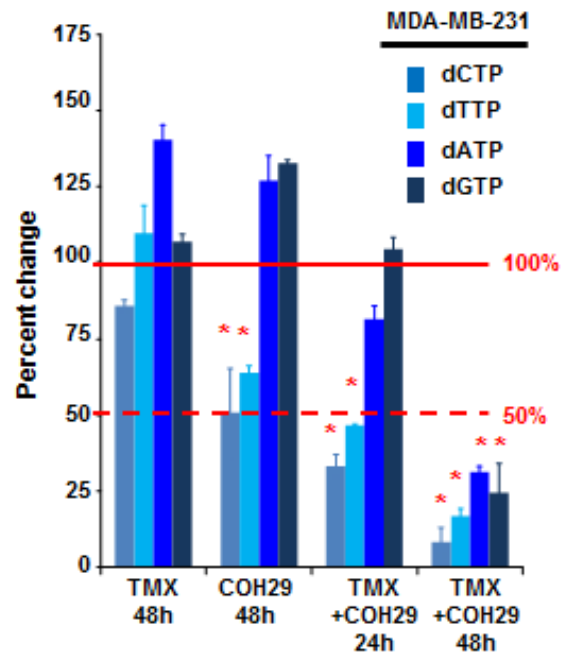

E

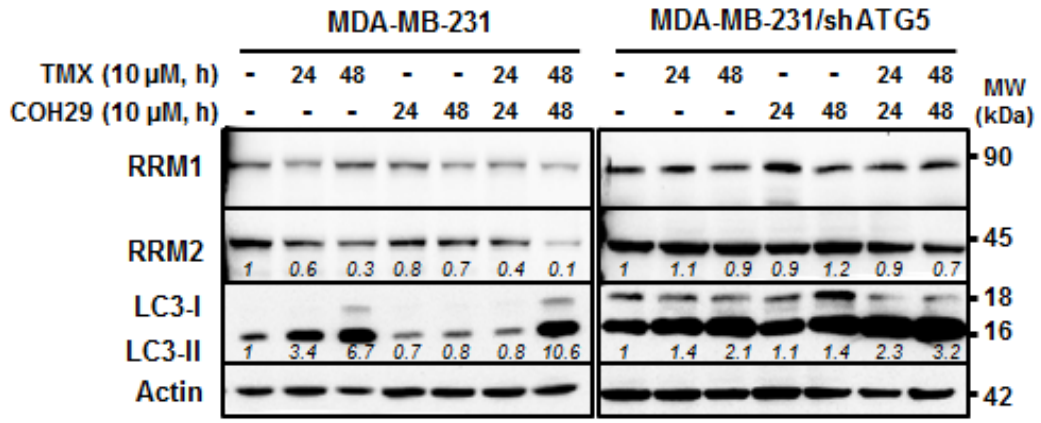

Figure 2: Autophagy is required for the synergistic effect between tamoxifen and COH29. A. Knockdown of ATG5 abolishes the synergistic cytotoxicity of the TMX + COH29 combination. MDA-MB-231 and MDA-MB-231/shATG5 cells were plated for the presence of indicated treatments. Cell viability was determined using the acid phosphatase assay at $72 \mathrm{~h}$ post-combined treatment and significance was determined relative to the no treatment control. Shown are the means $\pm \mathrm{SD} ; n=3 ;{ }_{*} p<0.05$. B. Synergistic effect of COH29 combined with TMX. Cytotoxicity data were evaluated for the combination index (CI) using CompuSyn software. The line shown in the plot indicates $\mathrm{CI}=1$ and values below 1 are defined as synergistic effects. $n=3$. C. Pre-treatment with TMX improves the effect of $\mathrm{COH} 29$. MDA-MB-231 cells were pre-treated with vehicle or TMX for $24 \mathrm{~h}$ prior to exposure to TMX and COH29, as indicated, for $72 \mathrm{~h}$. Chloroquine (CQ, $20 \mu \mathrm{M})$ addition significantly reversed the cytotoxic effects of $\mathrm{COH} 29$ and TMX. Results are shown as means $\pm \mathrm{SD} ; n$ $=3 ;{ }_{*} p<0.05$. D. Combination of TMX and COH29 decreases the intracellular dNTP pool. MDA-MB-231 cells were treated as indicated prior to cell harvesting. The intracellular abundance of dNTPs including dCTP, dTTP, dATP and dGTP was determined and the relative fold change in cells subjected to the indicated treatment was calculated by comparison to the no-treatment control. Results are shown as means \pm $\mathrm{SD} ; n=3 ;{ }_{* ;} p<0.05$. The solid line indicates $100 \%$ and the dashed line shows a $50 \%$ decrease. E. Autophagy is required to decrease RRM2 abundance. MDA-MB-231 and MDA-MB-231/shATG5 cells were subjected to treatment as indicated, followed by western analysis. One representative western blot from $n=3$ is shown. 
COH29 alone significantly decreased dCTP and dTTP abundance to $50 \%$ at $48 \mathrm{~h}$ post-treatment; however, the combined treatment showed a comparable effect at $24 \mathrm{~h}$ (Figure 2D). At $48 \mathrm{~h}$ after the combined treatment, all of the dNTP pools, including dCTP, dTTP, dATP and dGTP, were reduced to less than $25 \%$ of the control (Figure $2 \mathrm{D}$ ). Likewise, Western analyses revealed that TMX-induced LC3-II accumulation and RRM2 reduction were retarded by knocking-down ATG5 (Figure 2E). Although, the expression of RRM1 was not affected, the abundance of RRM2 is more reduced by the combination of TMX and $\mathrm{COH}$, which was consistent with the cytotoxicity data shown in Figure 2A. These results support our overall hypothesis that decreasing RR level decreases intracellular dNTP abundance.

Lastly, we investigated the possibility that other cell death pathways were activated by the combined treatment. To study the contribution of apoptosis to the cell death, MDAMB231 and MDAMB231/shATG5 cells were treated with a combination of TMX and $\mathrm{COH} 29$ for 24 and 48 h. The percentage of Annexin V-positive (early apoptotic) and/or PI-positive (dead) cells was determined by flow cytometry. The low percentage of cells undergoing early apoptosis suggested that apoptosis could not completely account for the observed death (Supplementary Figure $\mathrm{S} 3 \mathrm{~A}$ ). Western analyses further supported this finding by showing that the majority of caspase 3 remained inactivated (not cleaved) (Supplementary Figure S3B). Taken together, our results support the conclusion that the combined use of TMX and $\mathrm{COH}$ promoted cytotoxicity by autophagy induction.

\section{Reduced in vivo tumor progression after tamoxifen and $\mathrm{COH} 29$ administration}

Next, we used an orthotopic tumor model and treated the tumor-bearing mice with vehicle, TMX, $\mathrm{COH} 29$ or the combination. MDA-MB-231 and MDA-MB-231/ shATG5 cells were implanted into the mammary glands of NOD.Cg-Prkdc scid $I l 2 r g^{\mathrm{tm} 1 \mathrm{Wjl} / \mathrm{SzJ}}$ (NSG) (NOD-SCID) mice to form solid tumors and randomly divided into six groups with 5 mice each for the indicated treatments. Tumors were harvested at day 17 post-treatment and evaluated using hematoxylin and eosin (H\&E) staining. Figure $3 \mathrm{~A}$ shows the differences in tumor size among the groups. The tumor volume was recorded twice a week and plotted as shown in Figure 3B. The autophagycompetent, xenografted tumors showed significantly less growth in the presence of the combined TMX and $\mathrm{COH} 29$ treatment, relative to vehicle alone (Figure $3 \mathrm{~B}$ ) and also showed a reduced weight at the time of harvest (Figure 3C). However, consistent with Supplementary Figure $\mathrm{S} 1 \mathrm{C}$, the combined treatment had no effect on tumors from ATG5-knockdown MDA-MB-231 cells (Figure 3B). Furthermore, TMX and $\mathrm{COH} 29$ treatment, when delivered individually, did not reduce tumor growth (Figure 3C). Immunohistochemistry staining (IHC) of Ki67, a cellular marker for proliferation, was performed to assess tumor cell growth or not. The staining indicated that less Ki67 signals were detected in xenografted tumor cells from mice receiving the combined treatment of TMX and $\mathrm{COH} 29$ (Supplementary Figure S4A), consist with the significant reduction of tumor weights among four treatment groups (Figure 3C). Altogether, our results clearly show that TMX and $\mathrm{COH} 29$ have anti-tumor effects both in vitro and in vivo and suggest that autophagy is required for the combinatorial effect.

Next, the tumor samples were stained with antiRRM2 and -Ki67 antibodies, respectively (Figure 3D and Supplementary Figure S4A). The percentage of antiRRM2 positive cells per 500 cells in 2 tumor samples was enumerated. Figure 3D reveals that the nuclear RRM2 abundance was slightly reduced in the TMX-only group, unchanged in the COH29-only group, and markedly decreased in the group treated with $\mathrm{TMX}+\mathrm{COH} 29$. As expected, the $\mathrm{TMX}+\mathrm{COH} 29$ treatment only slightly reduced RRM2 abundance in tumors derived from autophagy-impaired MDA-MB-231/shATG5 cells (Figure 3D). These results were validated by Western analyses using protein samples extracted from the indicated tumors (Supplementary Figure S4B). In autophagy-competent MDA-MB-231-derived tumors, RRM1 abundance was not affected by the treatments, whereas RRM2 levels were reduced by combined treatment. Although we were unable to detect LC3-II, the LC3-I level decreased in TMX and became almost undetectable in the group received combined treatment, whereas unlipidated LC3 was notably visible in MDA-MB-231/shATG5-derived samples (Supplementary Figure S4B).

\section{Tamoxifen treatment enhances $\mathrm{COH} 29$-induced DNA damage and mitotic catastrophe}

In order to investigate the mechanism underlying breast cancer cell death by combined treatment with COH29 and TMX, fluorescence microscopy was used to examine the nuclear dynamics. As shown in Figure 4A, one striking feature was that $\mathrm{COH} 29$ treatment induced nuclear DNA leakage, as identified by DAPI-positive particles outside the nucleus, and the leaked DNA puncta were notably larger than micronuclei [36]. Furthermore, co-treatment with TMX enhanced the DNA leakage (Figure 4A). Lamins A and C, a structure that surrounds the nucleus, are the scaffolding components of the nuclear envelope in cells [37]. Notable features of this phenotype are a non-disrupted nuclear shape and an intact nuclear membrane, as shown by lamin A/C staining (Figure 4B). Intriguingly, some of the leaked DNAs were within laminlabeled structures (Figure 4B). Because dNTP depletion is known to induce genomic instability, we next wished 
A

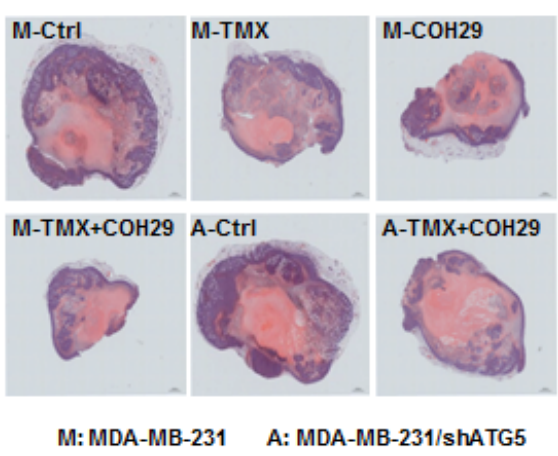

B

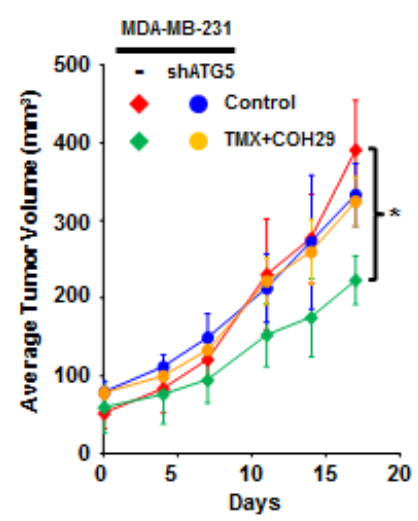

C

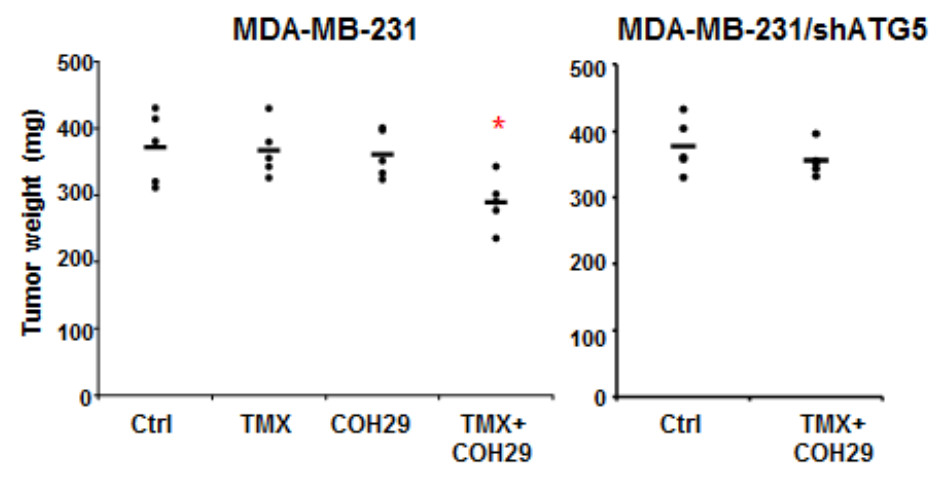

D
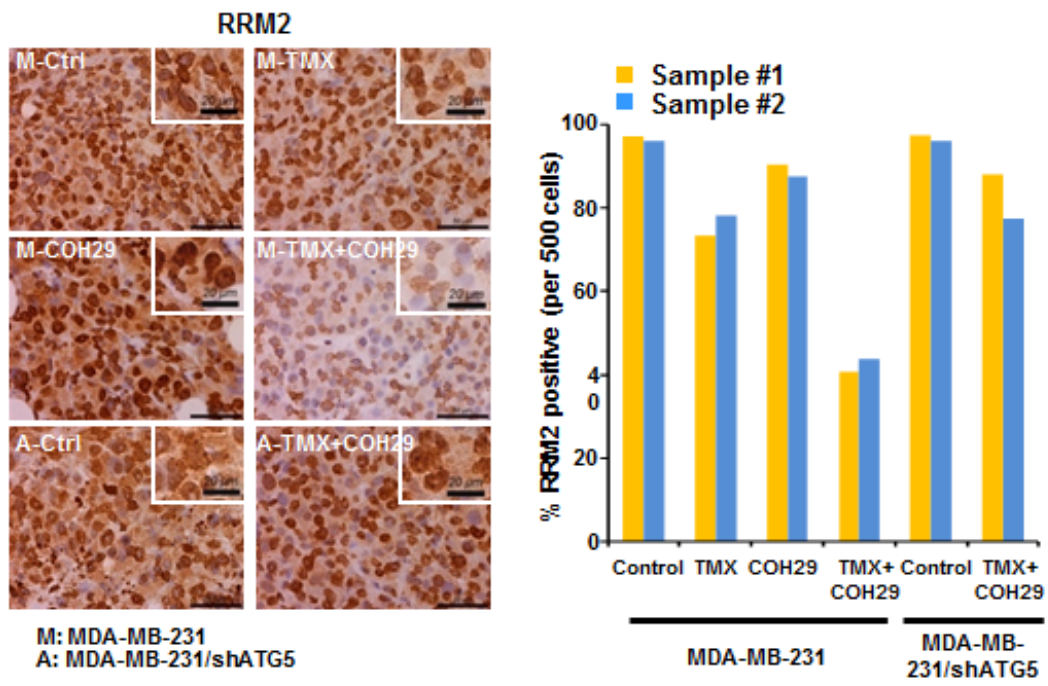

Figure 3: Combination of TMX and COH29 reduces tumor growth in vivo. A. Representative picture of harvested tumors after H\&E staining. M: MDA-MB-231 cells; A: MDA-MB-231/shATG cells; T: TMX (80 mg/kg/day, oral); COH: COH29 (30 mg/kg/day, i.p.); Ctrl: control; TMX + COH29: tamoxifen $(80 \mathrm{mg} / \mathrm{kg} /$ day, oral) plus COH29 (30 mg/kg/day, i.p.). B. Autophagy is required for combined TMX and COH29 to reduce tumor volume. Tumor growth over time is shown as the means $\pm \mathrm{SD}, n=5 ;{ }_{*}: p<0.05$. C. Autophagy is required for combined TMX and $\mathrm{COH} 29$ to reduce tumor weight. The tumor weight at harvest is shown. Each dot represents one mouse and the line indicates the average of the 5 samples. D. Combination of TMX and COH29 reduces RRM2 abundance. Representative immunostaining images of RRM2 staining are shown (left panels). Scale bar: $10 \mu \mathrm{m}$. The enlarged view is shown in the inlet; scale bar: 20 m. M: MDA-MB-231 cells; A: MDA-MB-231/shATG5 cells; T: TMX (80 mg/kg/day, oral); COH: COH29 (30 mg/kg/day, i.p.); Ctrl: control; TMX + COH29: TMX ( $80 \mathrm{mg} / \mathrm{kg} / \mathrm{day}$, oral) plus COH29 (30 mg/kg/day, i.p.). RRM2-positive cells per 500 cells were enumerated from each sample $(n=2)$ and the percentage was calculated by comparing to the control (designated as $100 \%)$. Each bar in the right panel represents one tumor sample. 
to assess the presence of DNA strand breaks. $\gamma \mathrm{H} 2 \mathrm{AX}$ is a phosphorylated histone protein that serves as a marker for double strand breaks. The percentage of cells that showed DNA leakage, $\gamma \mathrm{H} 2 \mathrm{AX}$ positivity or both was enumerated. Figure $4 \mathrm{C}$ shows that $\mathrm{COH} 29$-treatment induced DNA

A
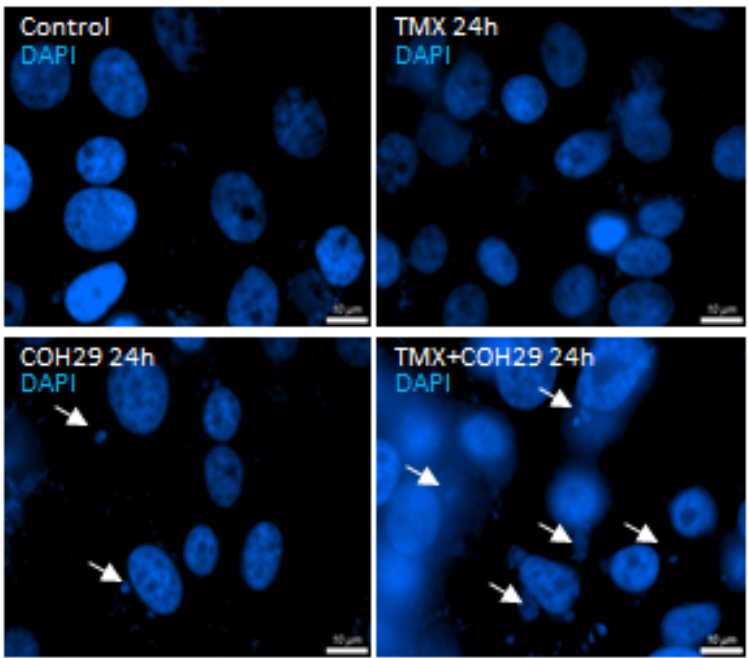

C
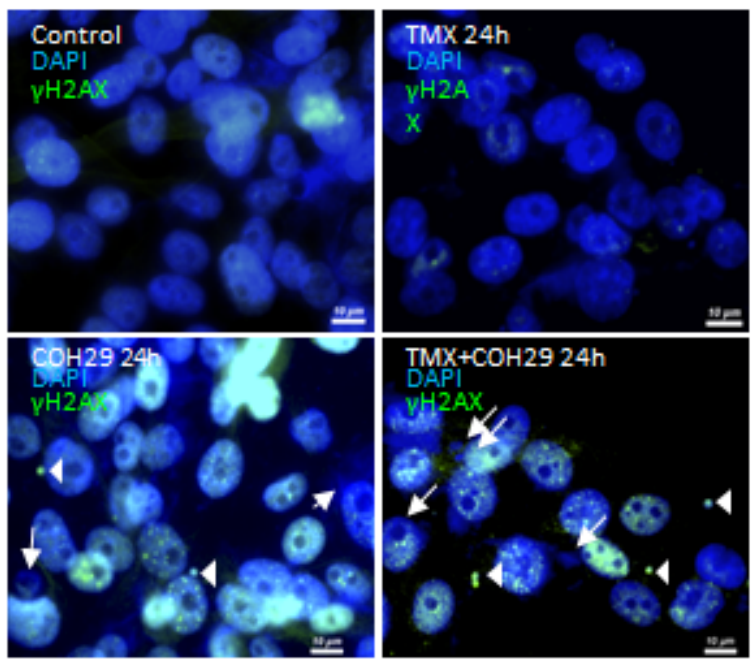

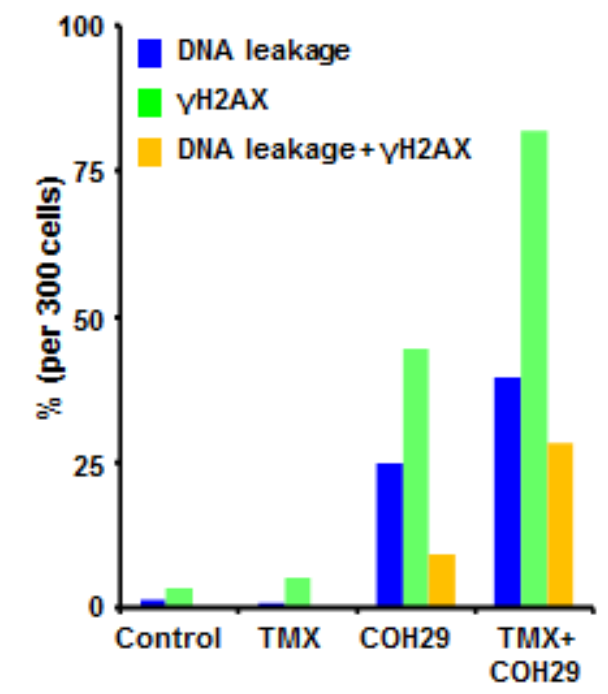

leakage and $\gamma \mathrm{H} 2 \mathrm{AX}$ positivity, and the $\mathrm{COH} 29+\mathrm{TMX}$ combination greatly enhanced this phenomenon. As expected, TMX treatment alone did not cause the accumulation of $\gamma \mathrm{H} 2 \mathrm{AX}$. Western analyses confirmed a slight increase of $\gamma \mathrm{H} 2 \mathrm{AX}$ abundance, which varied over

B

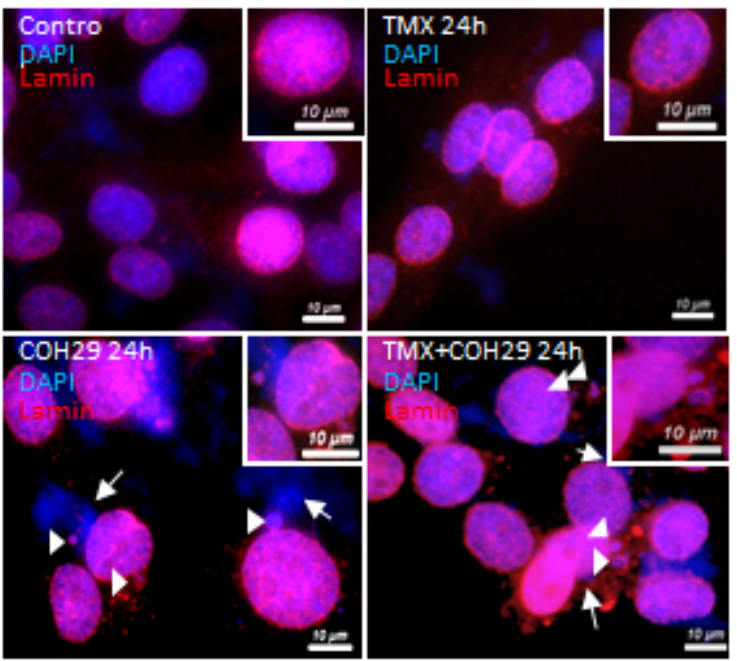

D

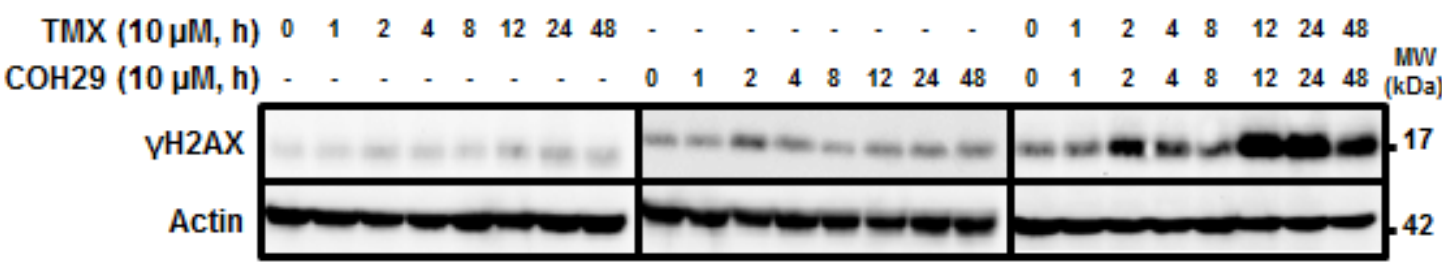

Figure 4: Combination of TMX and COH29 addition induces DNA leakage. MDA-MB-231 cells were treated with TMX, $\mathrm{COH}$ or the combination for the indicated time periods and stained with DAPI A., anti-lamin B. and anti- $\gamma \mathrm{H} 2 \mathrm{AX}(\mathrm{C}$, left panel). Arrows indicate the leaked DNA. Arrowheads depict the overlap of the leaked DNA with lamin B. or $\gamma \mathrm{H} 2 \mathrm{AX}$ staining $(\mathbf{C}$., right panel). The percentage of DNA leakage, $\gamma \mathrm{H} 2 \mathrm{AX}$ positive or containing both phenotype cells is calculated and plotted as a bar graph. scale bar: $10 \mu \mathrm{m}$. D. Western blot analysis showing the change in $\gamma \mathrm{H} 2 \mathrm{AX}$ abundance after TMX, $\mathrm{COH}$ and combination treatment. 
time in COH29-treated cells, (Figure 4D). In contrast, a more abundant $\gamma \mathrm{H} 2 \mathrm{AX}$ signal with extended duration was detected in combination-treated cells. It has been shown that autophagy plays a role in DNA damage response by cleaning up damaged DNAs [38-40]. As anticipated, knockdown of ATG5 induced a higher basal level of the basal $\gamma \mathrm{H} 2 \mathrm{AX}$ level in MDA-MB-231/shATG5 cells prior to $\mathrm{COH} 29$ or TMX treatment, and there was no significant increase of $\gamma \mathrm{H} 2 \mathrm{AX}$ level after treatment (Supplementary Figs. S5A and S5B).

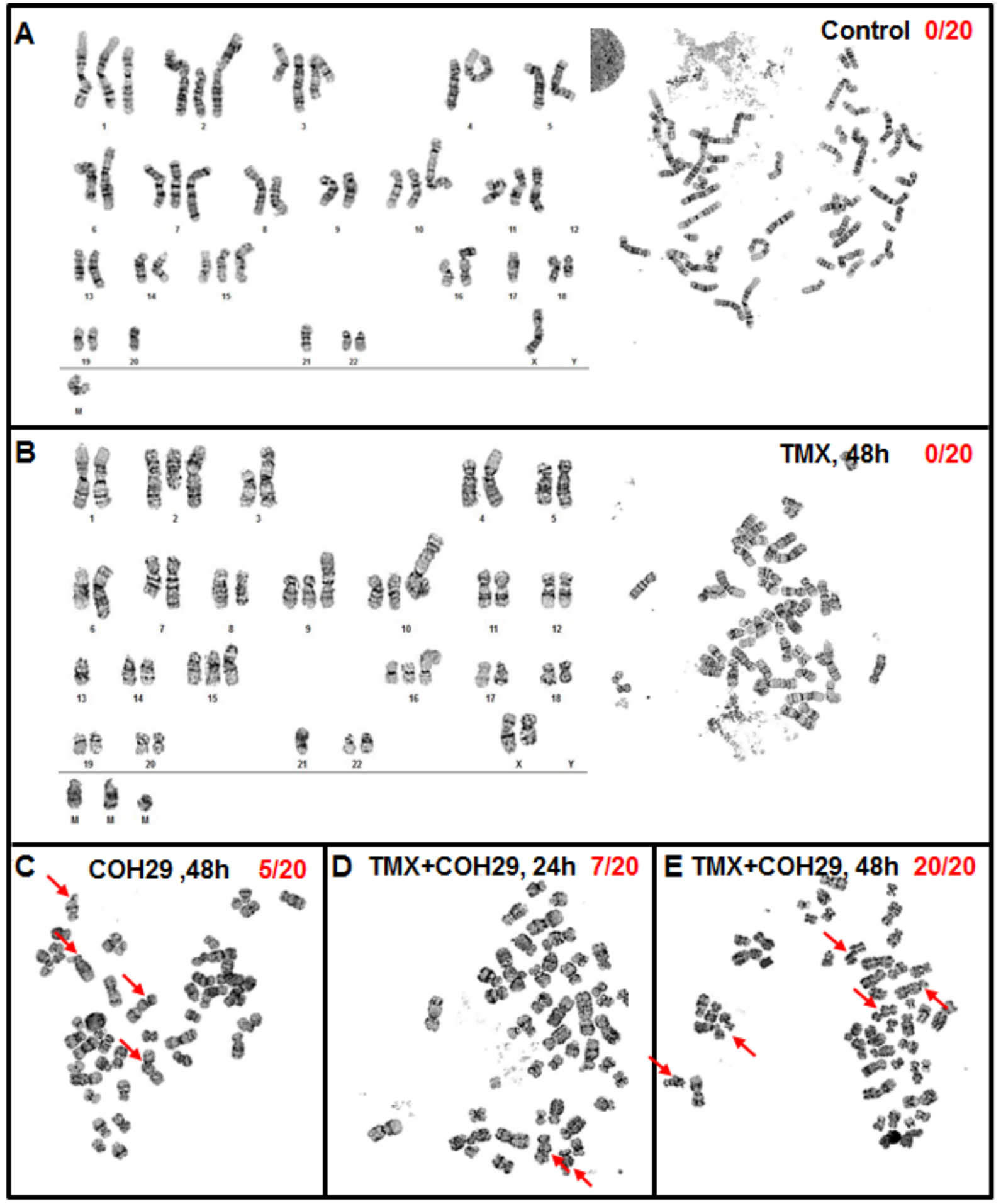

Figure 5: Combination of TMX and COH29 causes chromatin gaps and breakage. MDA-MB-231 cells were treated with TMX, COH29 for $48 \mathrm{~h}$ or the combination for 24 and $48 \mathrm{~h}$ and subjected to cytogenetic analysis. Control A., TMX $48 \mathrm{~h} \mathrm{B.,} \mathrm{COH} 48 \mathrm{~h} \mathrm{C.,}$ combination $24 \mathrm{~h} \mathrm{D}$. and $48 \mathrm{~h} \mathrm{E..} \mathrm{Arrows} \mathrm{indicate} \mathrm{the} \mathrm{chromatin} \mathrm{gaps} \mathrm{and} \mathrm{breakage.} \mathrm{The} \mathrm{numbers} \mathrm{shows} \mathrm{the} \mathrm{quantitation} \mathrm{of} \mathrm{the} \mathrm{breakage}$ as $\mathrm{X} / \mathrm{Y}$; $\mathrm{X}$ : cells showing chromatin break; Y: total cell number. 
In order to investigate the potential genomic instability induced by the combined of COH29 + TMX treatment, MDA-MB-231 cells undergoing various treatments were subjected to cytogenetic analysis (Figure 5). Serving a control, vehicle-treated MDAMB-231 cells showed an abnormal female karyotype with hyperdiploid and near tetraploid populations. The cells were characterized by structural abnormalities involving chromosomes $\mathrm{X}, 1,2,3,4,6,7,8,9,10$, $11,13,15,16,18$, and 21 . Clonal numerical gains of chromosomes $1,2,3,10,11$, and 15 were detected, as well as clonal losses of chromosome 21 (Figure 5A). The near tetraploid sideline cells contained duplicate copies of most stemline abnormalities. Using vehicle-treated MDA-MB-231 cells as a reference, we investigated the effects of drug treatment. A subset of the $\mathrm{COH} 29$-treated cells $(5 / 20)$ showed increases in genomic instability, including increases in chromosome and chromatid breaks and gaps, whereas TMX treated cells did not show any increased genomic instability (Figure. $5 \mathrm{~B}$ and $5 \mathrm{C}$ ). In the cells co-treated TMX and COH29 for $24 \mathrm{~h}$, the overall chromosomal morphology was significantly worse than that in vehicle-treated cells and chromosomal breakage was apparent in approximately 35\% of the cells (Figure 5D). At $48 \mathrm{~h}$ after combined treatment, chromosome and chromatid breaks and gaps were observed in almost all cells. In addition, all cells undergoing combined treatment for $48 \mathrm{~h}$ were arrested in metaphase, accompanied by shorter chromosome length and loss of chromosomes (Figure 5E). Taken together, these results suggested that $\mathrm{COH} 29$ treatment induced DNA damage, resulting in DNA leakage, which was markedly aggravated by combination with TMX.

\section{DISCUSSION}

RR inhibitors, first introduced into clinic near 60 years ago, are widely used in cancer therapy. The use of $\mathrm{RR}$ inhibitors as anti-cancer agents has been reviewed by Shao and colleagues $[11,41]$. Because rapidly dividing tumor cells have an increased need for dNTPs, they are far more sensitive to the cytotoxic effects of RR inhibition than normal cells. In addition, a growing body of evidence is showing that RRM2 is overexpressed in cancer and is associated with neoplasia, metastatic potential, and poor prognosis in human cancers [42-44].

60 years after the introduction of RR inhibitors into clinical oncology, their mechanism of action in human tumors is becoming increasingly clear. RR is a unique enzyme that utilizes free radicals to drive catalysis in a mechanism that involves components in both the RRM1 and RRM2 subunits $[45,46]$. The RRM1 subunit contains the active site and substrate specificity sites, whereas the RRM2 subunit contains the oxygen-linked diferric iron center and tyrosyl radical. Numerous small molecule inhibitors, such as hydroxyurea (HU), gemcitabine (both approved for human cancer clinical use) and triapine [47], interact with the RRM2 subunit and inhibit RR activity. However, these small molecules have problems that limit their use, including lack of specificity for the RRM2 protein, unwanted side effects, and susceptibility to resistance. For instance, HU blocks DNA synthesis by reducing the tyrosyl free radical of the RRM2 subunit to a normal tyrosine residue but is susceptible to resistance. Furthermore, 3-AP (triapine $\AA$ ), which was in human phase II clinical testing, relies on iron chelation to inactivate RR. Data from a phase I trial of 3-AP showed that patients developed side effects such as hypoxia, respiratory distress, and methemoglobulin, due to chelation of iron in the patients' red blood cells [48]. Therefore, approach to improve efficacy of existing RRM2 inhibitor or development of new RRM2 inhibitors are needed [49].

The reciprocal regulation of autophagy and the dNTP pool has been observed and reported in human cancer cells [28]. In this report, we have demonstrated that the ER-independent effect of TMX, autophagy induction, sensitizes ER $\alpha$-negative MDA-MB-231 cells to $\mathrm{COH} 29$, via RRM2 reduction. Studies on the combination of TMX with other agents, such as TRAIL [50] and rapamycin [51], have shown synergistic apoptotic activity. Although the concept of combined TMX with TRAIL therapy is worthwhile, the therapeutic use of TRAIL is limited by concerns over its potential hepatotoxicity $[52,53]$. Currently, TMX is associated with depression, endometrial hyperplasia, and Coumadin drug interaction. $\mathrm{COH} 29$ causes hematologic toxicity, such as anemia, thrombocytopenia, and leukemia. Theoretically, the side effects from the combination of TMX and COH29 should not exceed their respective adverse effect.

Two different ubiquitin ligases are known to exert tight control over the steady-state levels of RRM2 in the $\mathrm{G}_{1}$ - and $\mathrm{G}_{2}$-phases of cell cycle. During $\mathrm{G}_{1}$-phase, APC/ CCdh1, a multi-subunit E3 ubiquitin ligase complex, targets RRM2 for degradation [54]. During $\mathrm{G}_{2}$-phase, cyclin $\mathrm{F}$ controls the degradation of RRM2 [55]. In this report, we found that besides ubiquitin-mediated degradation of RRM2, the abundance of RRM2 was regulated by lysosomal degradation through autophagy induction. As shown in Figures. $1 \mathrm{C}$ and $2 \mathrm{C}$, the pretreatment of TMX (to induce autophagy) effectively reduced RRM2 level and sensitized cells to $\mathrm{COH} 29$. Moreover, the addition of BafA1, an autophagy inhibitor, blocked the decrease of RRM2 after autophagy induction by TMX, rapamycin and arginine depletion (Figure 1C, Supplementary Figs. S2A and S2C). All these suggest that autophagy-dependent lysosomal degradation plays a critical role in controlling RRM2 level in breast cancer cells. However, the underlying mechanism of how autophagy recognized RRM2 for degradation is still unclear and additional study is warranted. Although, we cannot rule out the possibility that increase in $\mathrm{COH} 29$ mediated cytotoxicity is due to increased drug intake via 
autophagy, we postulated that TMX-induced aggressive autophagy promotes the death of $\mathrm{COH} 29$-treated cells. This possibility is supported by the observation that some of the leaked DNAs were within lamin-labeled structures (Figure 4B), consistent with the report by GonzalezSuarez et al. that loss-of-lamin A affects the ability of cells to properly repair DNA damage and maintain genome integrity [56].

Anti-mitotic agents have wide-ranging therapeutic potential for the treatment of various types of cancers $[57,58]$ and there has been a great deal of interest in identifying novel mitotic inhibitors that can overcome the various modes of resistance and promote improved pharmacological profiles [59]. A previous report demonstrated that knockdown RRM2 and the addition of cisplatin induces inter- and intra-strand DNA crosslinks [60]. Also, a recent report from us showed that loss of RRM2b causes chromosomal instability and chromatid breakage in mice [61]. These findings showed that RRM2 plays a crucial role in maintaining chromosomal stability, suggesting that modulation of cellular RRM2 abundance may be important for the induction of mitotic cell death.

We propose that autophagic degradation of a RRM2, the target of $\mathrm{COH} 29$, promotes cell death, whereas in other contexts autophagy can protect cancer cells from death $[62,63]$. Why does autophagy promote tumor cell survival in some circumstances and death in other circumstances? One possible explanation relates to what autophagy is degrading in each specific circumstance. For example, starvation- or rapamycin-induced autophagy had been shown to decrease RRM2 level and accompanied by a decrease in RNR activity and dNTP pools in human cancer cells [30]. In our study, we showed that COH29 along can induce cell death through inhibiting RR activity, and its cytotoxicity is dramatic enhanced when autophagy is induced by TMX, even though the cells are normally resistant to TMX. In summary, the present findings indicate that combination of TMX and $\mathrm{COH} 29$ effectively reduces cell viability in MDA-MB-231 cells via an autophagy-dependent pathway. Furthermore, our data suggest that autophagy induction may serve as an adjuvant anticancer therapy, and that proper combined treatment with an autophagy inducer could synergistically enhance the therapeutic efficacy of a myriad of cancer treatments.

\section{MATERIALS AND METHODS}

\section{Cell lines, media and chemicals}

MDA-MB-231, MDA-MB-231/sh-ATG5 (ATG5 knockdown [5]), MDA-MB-231/GFP-LC3 (stable GFPLC3 overexpression [5]) and MCF-7 cells were cultured in Dulbecco's modified Eagle's medium (DMEM) (Cellgro, 10-013-CV) containing fetal bovine serum (10\%; Gibco,
26140), penicillin $(100 \mathrm{U} / \mathrm{ml})$ and streptomycin $(100 \mu \mathrm{g} /$ $\mathrm{ml})(\mathrm{Gibco}, 15240)$ at $37{ }^{\circ} \mathrm{C}$ and $5 \% \mathrm{CO}_{2}$ in a humidified incubator. T47D cells were cultured in RPMI 1640 medium under similar conditions. MCF-10A cells were maintained in DMEM/F12 media supplied with 5\% horse serum, $20 \mathrm{ng} / \mathrm{mL}$ EGF, $0.5 \mathrm{mg} / \mathrm{mL}$ hydrocortisone, $100 \mathrm{ng} /$ $\mathrm{mL}$ cholera toxin, $10 \mu \mathrm{g} / \mathrm{mL}$ insulin (Invitrogen, Carlsbad, CA, USA). Rapamycin (R8781), tamoxifen (T5648), bafilomycin A1 (B1793) and Chloroquine diphosphate salt (C6628) were from Sigma. Recombinant ADI-PEG20 was a gift of Polaris Pharmaceuticals Inc. (San Diego, CA).

\section{Antibodies}

The anti-MAP1LC3-I/II antibody (4599 and 3868), anti-lamin (4777) and anti-caspase-3 antibody (9665) were from Cell Signaling, and the anti-SQSTM1 (p62/ SQSTM1) antibody (sc-28359), anti-RRM1 antibody (sc11733) and anti-RRM2 antibody (sc-10844) were from Santa Cruz. The anti-Ki67 antibody (ab15580) was from Abcam, and the anti-p53R2 antibody (600-401-B67) was from Rockland. The anti- $\gamma \mathrm{H} 2 \mathrm{AX}$ antibody (05-636) and anti-actin antibody (MAB1501R) were from Millipore.

\section{Cytotoxicity and apoptosis assays}

Many cytotoxicity assays are dependent on mitochondrial function and can generate artifacts if mitochondrial function is impaired without cell death. Therefor, ACP assays, which measures cellular acid phosphatase activity, were used to avoid the effects of mitochondria dysfunction. Between 2,500 and 5,000 cells were seeded onto 96-well plates. Cells were treated with TMX, $\mathrm{COH}$ or the combination at the indicated concentrations for $72 \mathrm{~h}$. At the end of the time period, cells were washed twice with PBS then incubated at 37 ${ }^{\circ} \mathrm{C}$ for $30 \mathrm{~min}$ with $100 \mu \mathrm{l}$ of pNPP solution composed of pNPP $(5 \mathrm{mM})$ in a buffer containing sodium acetate $(0.1$ $\mathrm{M})$ and Triton $\mathrm{X}-100(0.1 \%(\mathrm{v} / \mathrm{v}), \mathrm{pH} 5.5)$. The reaction was terminated by adding $\mathrm{NaOH}(1 \mathrm{~N}, 10 \mu \mathrm{l})$, and the absorbance was measured at $410 \mathrm{~nm}$ using a microplate reader. The interaction between drug combinations was analyzed using the Calcusyn software program (Biosoft, Cambridge, UK) to determine if the combination was antagonistic, additive or synergistic. This program is based on the Chou-Talalay method to calculate a CI, and CI values below 1 indicate synergistic effect. The CIs were determined from cell viability ACP assays as the fraction of cells killed by individual drugs, or combination of drugs, compared to vehicle-treated cells. For the apoptosis assay, cells were treated with $\mathrm{COH} 29$ and TMX for the indicated time periods. After trypsinization, cells were washed twice with cold PBS and collected by centrifugation at $1000 \mathrm{rpm}$. Cells were then resuspended in $1 \times$ Binding Buffer at a concentration of $1 \times 10^{6}$ cells/ 
$\mathrm{ml}$ and $100 \mu \mathrm{l}$ of the suspension $\left(1 \times 10^{5}\right.$ cells $)$ was transferred to a polystyrene round-bottom tube. Cells were then stained with FITC-conjugated Annexin V (4 $\mu \mathrm{l})$ and propidium iodide $(\mathrm{PI})(50 \mu \mathrm{g} / \mathrm{ml}, 5 \mu \mathrm{l})$. The mixture was gently vortexed and incubated for $15 \mathrm{~min}$ at RT and $1 \mathrm{x}$ Binding Buffer $(400 \mu \mathrm{l})$ was added to each tube before analyzing by flow cytometry.

\section{Whole-cell Extracts and Immunoblotting}

Cells treated with TMX, $\mathrm{COH}$ or combination treatment were harvested at the end of incubation period and lysed on ice for $30 \mathrm{~min}$ in RIPA buffer (Cell Signaling, \#9806) containing a complete protease inhibitor cocktail (Roche, 11836145001) and PhosSTOP (Roche, 04906837001). The Qproteome Mammalian Protein Prep Kit (Qiagen) was used to extract protein from harvested tumors. The protein concentrations were determined using a Bio-Rad Protein Assay Kit (Bio-Rad, 500-0001). Approximately $40 \mu \mathrm{g}$ of protein was mixed with an equal volume of $2 \times$ SDS loading buffer, boiled for $5 \mathrm{~min}$, then separated by Tris-glycine SDS-PAGE and transferred to PVDF membranes. The membranes were blocked with 5\% nonfat milk in PBST (PBS containing $0.05 \%$ Tween 20) and incubated with primary antibodies at $4{ }^{\circ} \mathrm{C}$ overnight. The membranes were then washed with three times with PBST for $10 \mathrm{~min}$, and incubated with HRP (horseradish peroxidase)-labeled secondary antibodies for $2 \mathrm{~h}$ at RT. Immunoblots were visualized using the VersaDoc 5000 imaging system (Bio-Rad) and processed using quantity one (Bio-Rad).

\section{Isolating dNTPs}

$1 \times 10^{6}$ cell pellets were harvested and added to 100 $\mu \mathrm{l}$ of $15 \%$ trichloroacetic acid. Alternatively, $50 \mathrm{mg}$ of tumor samples were added to $100 \mu \mathrm{l}$ of $15 \%$ trichloroacetic acid. The solution was mixed and homogenized using a TissueLyser (Qiagen) for $1 \mathrm{~min}$ then kept on ice for 10 $\min$. Then the mixture was centrifuged for $5 \mathrm{~min}$, and the supernatant fractions were saved and extracted with $2 \times 50$ $\mu 1$ aliquots of 1,1,2-trichlorotrifluoroethane/trioctylamine (55:45; Sigma-Aldrich,270369, and T81000). After each centrifugation, the supernatant was saved. $5 \mu$ laliquots of each sample were used to check the dATP, dCTP, dGTP, and dTTP concentrations. The remainder was stored at -80 ${ }^{\circ} \mathrm{C}$ for further assays.

\section{dNTP pool assay}

This assay was conducted according to the method of Sherman and Fyfe. The total reaction volume was 50 $\mu 1$. The reaction mixture contained $50 \mathrm{mM}$ of Tris- $\mathrm{HCl}$ (pH 7.5), $10 \mathrm{mM}$ of $\mathrm{MgCl} 2,5 \mathrm{mM}$ of DTT, $0.25 \mathrm{mM}$ of template/primer, $1.25 \mathrm{mM}$ of $\left[{ }^{3} \mathrm{H}\right] \mathrm{dATP}$ (for dCTP, dGTP, and dTTP assay) or $\left[{ }^{3} \mathrm{H}\right] \mathrm{dTTP}$ (for dATP assay), and 0.2 units of Sequenase (2.0) (Affymetrix, 70775Y). After reacting at room temperature (RT) for $20 \mathrm{~min}, 40 \mu \mathrm{l}$ of the aliquots were applied to circular Whatman DE81 ion exchange paper (GE Healthcare Life Sciences, 3658-325). The papers were dried, then washed $3 \times 10$ min with $5 \%$ $\mathrm{Na}_{2} \mathrm{HPO}_{4}$, and rinsed once with distilled water and once more with $95 \%$ ethanol. After each paper was dried and deposited in a small test tube, and $5 \mathrm{ml}$ of Ecoscint A was added to each tube. Tritium-labeled dNTPs were counted in a liquid scintillation counter and compared to a standard sample prepared in the presence of $0,0.25,0.50,0.75$ and $1.0 \mathrm{pmol} / \mathrm{ml}$ of dATP, dTTP, dGTP, and dCTP each.

\section{Microscopy}

MDA-MB-231/GFP-LC3 cells were cultured in sixwell plates with cover slips at a density of $1 \times 10^{5}$ cells/ well, and then treated with TMX, $\mathrm{COH}$ or the combination for the indicated time points. After washing with PBS, the cover slips were mounted over a microscope slide in Prolong anti-fade reagent that contained DAPI (Life Technologies, P-36931), and examined using a Olympus AX70 upright microscope (Olympus).

\section{Xenograft studies}

For tumorigenesis, $5 \times 10^{6} \mathrm{MDA}-\mathrm{MB}-231$ and MDA-MB-231/sh-ATG5 cells (resuspended in $100 \mu \mathrm{l}$ serum-free DMEM media) were used for orthotopic implantation of six-week-old female NOD.Cg$P r k d c^{\mathrm{scid}} I l 2 \mathrm{rg}^{\mathrm{tm} l \mathrm{Wjl}} / \mathrm{SzJ}$ (NSG) (NOD-SCID) mice. Mice were randomized at day 10 after tumor inoculation and received vehicle, an approximate total dose of $30 \mathrm{mg} / \mathrm{kg}$ of $\mathrm{COH} 29,80 \mathrm{mg} / \mathrm{kg}$ of TMX, or the combination therapy daily for 17 days ( $n=5$ per group). The tumor volume was measured twice every week. Tumors were harvested for weight measurement and H\&E, RRM2 and Ki67 staining. All animal experiments were approved by the institutional animal care and use committee at City of Hope.

\section{Immunohistochemistry (IHC)}

Ki67 and RRM2 protein levels in the tumor samples harvest from mouse were assessed by IHC using antiKi67 (1:100 dilution) and anti-RRM2 antibodies (1:75 dilution). Briefly, after de-paraffinization, endogenous peroxidase activity was blocked by pre-treatment with $3 \% \mathrm{H}_{2} \mathrm{O}_{2}$. The slides were incubated with normal goat serum for $20 \mathrm{~min}$ at RT to block non-specific signal, then incubated with the primary antibody for $20 \mathrm{~min}$ at RT. The slides were then incubated with polymer horseradish peroxidase-labeled secondary antibodies for $30 \mathrm{~min}$ at RT, 
then 3,3-Diaminobenzidine (DAB)-treated (0.05 g DAB and $100 \mathrm{ml} 30 \% \mathrm{H}_{2} \mathrm{O}_{2}$ in $100 \mathrm{ml} \mathrm{PBS}$ ) for 5 and $10 \mathrm{~min}$, respectively.

\section{Statistical analysis}

Data analysis was performed using GraphPad Prism 5.0 software or Microsoft excel. Each cell biology experiment was performed in triplicate to obtain representative means and images. Statistical significant was set as $p<0.05$, two-tailed.

\section{ACKNOWLEDGMENTS}

We are sincerely grateful to Dr. Brian Armstrong and Ms. Tina Patel of the Light Microscopy Digital Imaging Core at City of Hope for confocal and fluorescent microscopy analyses, Ms. Sofia Loera of the Pathology Core at City of Hope for immunohistochemical analyses, Ms. Lucy Brown of the Analytical Cytometry Core at City of Hope for flow cytometry analyses, Dr. Joyce Collins and Ms. Victoria Bedell of the Cytogenetics Core of City of Hope for cytogenetic investigation, Ms. Yiyin Chung and Ms. Sze-min Lin for their help on the animal experiments, Dr. Hsiu-Ming Shih and the RNAi Consortium at Academia Sinica for providing the lentiviral constructs against human ATG5, members of Ann's laboratory for helpful discussions, and Dr. Nancy Linford for editing.

\section{Authors' contributions}

Y.R.C., B.T. and D.A. designed the experiments and analyzed the data. Y.R.C., B.T., S.H. and H.M. executed experiments. Y.R.C., Y.Y. and D.A. wrote the manuscript. Y.R.C. and X.L. performed statistical analyses.

\section{CONFLICTS OF INTEREST}

The authors have no financial conflicts of interest to disclose.

\section{FINANCIAL SUPPORT}

This work was supported in part by National Institute of Health Research Grants R01DE10742 and R01DE14183 and the Mary Kay Foundation Research Grant number 005-13 (to D.K.A.), City of Hope's Women's Cancers Program Award (to Y-R.C.) and P30CA33572.

\section{REFERENCES}

1. Kroemer G, Galluzzi L, Vandenabeele P, Abrams J, Alnemri ES, Baehrecke EH, Blagosklonny MV, ElDeiry WS, Golstein P, Green DR, Hengartner M, Knight RA, Kumar S, Lipton SA, Malorni W, Nunez G, et al. Classification of cell death: recommendations of the Nomenclature Committee on Cell Death 2009. Cell death and differentiation. 2009; 16:3-11.

2. Klionsky DJ. Autophagy: from phenomenology to molecular understanding in less than a decade. Nature reviews Molecular cell biology. 2007; 8:931-937.

3. Mizushima N, Levine B, Cuervo AM and Klionsky DJ. Autophagy fights disease through cellular self-digestion. Nature. 2008; 451:1069-1075.

4. Eskelinen EL and Saftig P. Autophagy: a lysosomal degradation pathway with a central role in health and disease. Biochimica et biophysica acta. 2009; 1793:664673.

5. Qiu F, Chen YR, Liu X, Chu CY, Shen LJ, Xu J, Gaur S, Forman HJ, Zhang H, Zheng S, Yen Y, Huang J, Kung HJ and Ann DK. Arginine starvation impairs mitochondrial respiratory function in ASS1-deficient breast cancer cells. Science signaling. 2014; 7:ra31.

6. Changou CA, Chen YR, Xing L, Yen Y, Chuang FY, Cheng RH, Bold RJ, Ann DK and Kung HJ. Arginine starvationassociated atypical cellular death involves mitochondrial dysfunction, nuclear DNA leakage, and chromatin autophagy. Proceedings of the National Academy of Sciences of the United States of America. 2014; 111:1414714152.

7. Speirs CK, Hwang M, Kim S, Li W, Chang S, Varki V, Mitchell L, Schleicher S and Lu B. Harnessing the cell death pathway for targeted cancer treatment. American journal of cancer research. 2011; 1:43-61.

8. Oliver FJ, Collins MK and Lopez-Rivas A. dNTP pools imbalance as a signal to initiate apoptosis. Experientia. 1996; 52:995-1000.

9. Nordlund P and Reichard P. Ribonucleotide reductases. Annu Rev Biochem. 2006; 75:681-706.

10. Nilsson R, Jain M, Madhusudhan N, Sheppard NG, Strittmatter L, Kampf C, Huang J, Asplund A and Mootha VK. Metabolic enzyme expression highlights a key role for MTHFD2 and the mitochondrial folate pathway in cancer. Nature communications. 2014; 5:3128.

11. Shao J, Zhou B, Chu B and Yen Y. Ribonucleotide reductase inhibitors and future drug design. Curr Cancer Drug Targets. 2006; 6:409-431.

12. Zhou B, Su L, Hu S, Hu W, Yip ML, Wu J, Gaur S, Smith DL, Yuan YC, Synold TW, Horne D and Yen Y. A smallmolecule blocking ribonucleotide reductase holoenzyme formation inhibits cancer cell growth and overcomes drug resistance. Cancer research. 2013; 73:6484-6493. 
13. Osborne CK. Tamoxifen in the treatment of breast cancer. The New England journal of medicine. 1998; 339:16091618.

14. Criscitiello C, Fumagalli D, Saini KS and Loi S. Tamoxifen in early-stage estrogen receptor-positive breast cancer: overview of clinical use and molecular biomarkers for patient selection. OncoTargets and therapy. 2011; 4:1-11.

15. Smith CL, Nawaz Z and O'Malley BW. Coactivator and corepressor regulation of the agonist/antagonist activity of the mixed antiestrogen, 4-hydroxytamoxifen. Molecular endocrinology. 1997; 11:657-666.

16. Early Breast Cancer Trialists' Collaborative G. Effects of chemotherapy and hormonal therapy for early breast cancer on recurrence and 15-year survival: an overview of the randomised trials. Lancet. 2005; 365:1687-1717.

17. Osborne CK, Yochmowitz MG, Knight WA, 3rd and McGuire WL. The value of estrogen and progesterone receptors in the treatment of breast cancer. Cancer. 1980; 46:2884-2888.

18. Theriault RL, Carlson RW, Allred C, Anderson BO, Burstein HJ, Edge SB, Farrar WB, Forero A, Giordano SH, Goldstein LJ, Gradishar WJ, Hayes DF, Hudis CA, Isakoff SJ, Ljung BM, Mankoff DA, et al. Breast cancer, version 3.2013: featured updates to the NCCN guidelines. Journal of the National Comprehensive Cancer Network. 2013; 11:753-760; quiz 761.

19. Obrero M, Yu DV and Shapiro DJ. Estrogen receptordependent and estrogen receptor-independent pathways for tamoxifen and 4-hydroxytamoxifen-induced programmed cell death. The Journal of biological chemistry. 2002; 277:45695-45703.

20. Blackwell KL, Haroon ZA, Shan S, Saito W, Broadwater G, Greenberg CS and Dewhirst MW. Tamoxifen inhibits angiogenesis in estrogen receptor-negative animal models. Clinical cancer research. 2000; 6:4359-4364.

21. Powles TJ, Ashley S, Tidy A, Smith IE and Dowsett M. Twenty-year follow-up of the Royal Marsden randomized, double-blinded tamoxifen breast cancer prevention trial. Journal of the National Cancer Institute. 2007; 99:283-290.

22. Bursch W, Ellinger A, Kienzl H, Torok L, Pandey S, Sikorska M, Walker R and Hermann RS. Active cell death induced by the anti-estrogens tamoxifen and ICI 164384 in human mammary carcinoma cells (MCF-7) in culture: the role of autophagy. Carcinogenesis. 1996; 17:1595-1607.

23. Gonzalez-Malerva L, Park J, Zou L, Hu Y, Moradpour Z, Pearlberg J, Sawyer J, Stevens H, Harlow E and LaBaer J. High-throughput ectopic expression screen for tamoxifen resistance identifies an atypical kinase that blocks autophagy. Proceedings of the National Academy of Sciences of the United States of America. 2011; 108:20582063.

24. Karantza-Wadsworth V, Patel S, Kravchuk O, Chen G, Mathew R, Jin S and White E. Autophagy mitigates metabolic stress and genome damage in mammary tumorigenesis. Genes \& development. 2007; 21:1621-1635.

25. Mathew R, Kongara S, Beaudoin B, Karp CM, Bray K, Degenhardt K, Chen G, Jin S and White E. Autophagy suppresses tumor progression by limiting chromosomal instability. Genes \& development. 2007; 21:1367-1381.

26. White E. Deconvoluting the context-dependent role for autophagy in cancer. Nature reviews Cancer. 2012; 12:401410.

27. Onodera $\mathrm{J}$ and Ohsumi Y. Autophagy is required for maintenance of amino acid levels and protein synthesis under nitrogen starvation. The Journal of biological chemistry. 2005; 280:31582-31586.

28. Ito H, Daido S, Kanzawa T, Kondo S and Kondo Y. Radiation-induced autophagy is associated with LC3 and its inhibition sensitizes malignant glioma cells. International journal of oncology. 2005; 26:1401-1410.

29. Katayama M, Kawaguchi T, Berger MS and Pieper RO. DNA damaging agent-induced autophagy produces a cytoprotective adenosine triphosphate surge in malignant glioma cells. Cell death and differentiation. 2007; 14:548558.

30. Chen W, Zhang L, Zhang K, Zhou B, Kuo ML, Hu S, Chen L, Tang M, Chen YR, Yang L, Ann DK and Yen Y. Reciprocal regulation of autophagy and dNTP pools in human cancer cells. Autophagy. 2014; 10:1272-1284.

31. Zhang H, Liu X, Warden CD, Huang Y, Loera S, Xue L, Zhang S, Chu P, Zheng S and Yen Y. Prognostic and therapeutic significance of ribonucleotide reductase small subunit M2 in estrogen-negative breast cancers. BMC cancer. 2014; 14:664.

32. Kohli L, Kaza N, Coric T, Byer SJ, Brossier NM, Klocke BJ, Bjornsti MA, Carroll SL and Roth KA. 4-Hydroxytamoxifen induces autophagic death through K-Ras degradation. Cancer research. 2013; 73:4395-4405.

33. Cho KS, Yoon YH, Choi JA, Lee SJ and Koh JY. Induction of autophagy and cell death by tamoxifen in cultured retinal pigment epithelial and photoreceptor cells. Investigative ophthalmology \& visual science. 2012; 53:5344-5353.

34. Shacka JJ, Klocke BJ and Roth KA. Autophagy, bafilomycin and cell death: the "a-B-cs" of plecomacrolideinduced neuroprotection. Autophagy. 2006; 2:228-230.

35. Yoshimori T, Yamamoto A, Moriyama Y, Futai M and Tashiro Y. Bafilomycin A1, a specific inhibitor of vacuolartype $\mathrm{H}(+)$-ATPase, inhibits acidification and protein degradation in lysosomes of cultured cells. The Journal of biological chemistry. 1991; 266:17707-17712.

36. Belien JA, Copper MP, Braakhuis BJ, Snow GB and Baak JP. Standardization of counting micronuclei: definition of a protocol to measure genotoxic damage in human exfoliated cells. Carcinogenesis. 1995; 16:2395-2400.

37. Goldman RD, Gruenbaum Y, Moir RD, Shumaker DK and Spann TP. Nuclear lamins: building blocks of nuclear architecture. Genes Dev. 2002; 16:533-547.

38. Robert T, Vanoli F, Chiolo I, Shubassi G, Bernstein KA, 
Rothstein R, Botrugno OA, Parazzoli D, Oldani A, Minucci $\mathrm{S}$ and Foiani M. HDACs link the DNA damage response, processing of double-strand breaks and autophagy. Nature. 2011; 471:74-79.

39. Czarny P, Pawlowska E, Bialkowska-Warzecha J, Kaarniranta K and Blasiak J. Autophagy in DNA damage response. International journal of molecular sciences. 2015; 16:2641-2662.

40. Filomeni G, De Zio D and Cecconi F. Oxidative stress and autophagy: the clash between damage and metabolic needs. Cell death and differentiation. 2015; 22:377-388.

41. Chen MC, Zhou B, Zhang K, Yuan YC, Un F, Hu S, Chou $\mathrm{CM}$, Chen CH, Wu J, Wang Y, Liu X, Smith L, Warden CD, Liu Z, Li H, Su L, et al. The Novel Ribonucleotide Reductase Inhibitor COH29 Inhibits DNA Repair In Vitro. Molecular pharmacology. 2015.

42. Kretschmer C, Sterner-Kock A, Siedentopf F, Schoenegg W, Schlag PM and Kemmner W. Identification of early molecular markers for breast cancer. Molecular cancer. 2011; 10:15.

43. Morikawa T, Maeda D, Kume H, Homma Y and Fukayama M. Ribonucleotide reductase M2 subunit is a novel diagnostic marker and a potential therapeutic target in bladder cancer. Histopathology. 2010; 57:885-892.

44. Morikawa T, Hino R, Uozaki H, Maeda D, Ushiku T, Shinozaki A, Sakatani T and Fukayama M. Expression of ribonucleotide reductase M2 subunit in gastric cancer and effects of RRM2 inhibition in vitro. Human pathology. 2010; 41:1742-1748.

45. Stubbe J, Nocera DG, Yee CS and Chang MC. Radical initiation in the class I ribonucleotide reductase: long-range proton-coupled electron transfer? Chemical reviews. 2003; 103:2167-2201.

46. Lendzian F. Structure and interactions of amino acid radicals in class I ribonucleotide reductase studied by ENDOR and high-field EPR spectroscopy. Biochimica et biophysica acta. 2005; 1707:67-90.

47. Yen Y, Margolin K, Doroshow J, Fishman M, Johnson B, Clairmont C, Sullivan D and Sznol M. A phase I trial of 3-aminopyridine-2-carboxaldehyde thiosemicarbazone in combination with gemcitabine for patients with advanced cancer. Cancer chemotherapy and pharmacology. 2004; 54:331-342.

48. Gojo I, Tidwell ML, Greer J, Takebe N, Seiter K, Pochron MF, Johnson B, Sznol M and Karp JE. Phase I and pharmacokinetic study of Triapine, a potent ribonucleotide reductase inhibitor, in adults with advanced hematologic malignancies. Leukemia research. 2007; 31:1165-1173.

49. Nocentini G. Ribonucleotide reductase inhibitors: new strategies for cancer chemotherapy. Critical reviews in oncology/hematology. 1996; 22:89-126.

50. Lagadec C, Adriaenssens E, Toillon RA, Chopin V, Romon R, Van Coppenolle F, Hondermarck H and Le Bourhis X. Tamoxifen and TRAIL synergistically induce apoptosis in breast cancer cells. Oncogene. 2008; 27:1472-1477.

51. deGraffenried LA, Friedrichs WE, Russell DH, Donzis EJ, Middleton AK, Silva JM, Roth RA and Hidalgo M. Inhibition of mTOR activity restores tamoxifen response in breast cancer cells with aberrant Akt Activity. Clinical cancer research. 2004; 10:8059-8067.

52. Daniel PT, Wieder T, Sturm I and Schulze-Osthoff K. The kiss of death: promises and failures of death receptors and ligands in cancer therapy. Leukemia. 2001; 15:1022-1032.

53. Wajant H, Pfizenmaier K and Scheurich P. TNF-related apoptosis inducing ligand (TRAIL) and its receptors in tumor surveillance and cancer therapy. Apoptosis. 2002; 7:449-459.

54. D'Angiolella V, Donato V, Forrester FM, Jeong YT, Pellacani C, Kudo Y, Saraf A, Florens L, Washburn MP and Pagano M. Cyclin F-mediated degradation of ribonucleotide reductase M2 controls genome integrity and DNA repair. Cell. 2012; 149:1023-1034.

55. Chabes AL, Pfleger CM, Kirschner MW and Thelander L. Mouse ribonucleotide reductase R2 protein: a new target for anaphase-promoting complex-Cdh1-mediated proteolysis. Proceedings of the National Academy of Sciences of the United States of America. 2003; 100:3925-3929.

56. Gonzalez-Suarez I, Redwood AB, Perkins SM, Vermolen B, Lichtensztejin D, Grotsky DA, Morgado-Palacin L, Gapud EJ, Sleckman BP, Sullivan T, Sage J, Stewart CL, Mai $\mathrm{S}$ and Gonzalo S. Novel roles for A-type lamins in telomere biology and the DNA damage response pathway. The EMBO journal. 2009; 28:2414-2427.

57. Jackson JR, Patrick DR, Dar MM and Huang PS. Targeted anti-mitotic therapies: can we improve on tubulin agents? Nature reviews Cancer. 2007; 7:107-117.

58. Castedo M, Perfettini JL, Roumier T, Andreau K, Medema $\mathrm{R}$ and Kroemer G. Cell death by mitotic catastrophe: a molecular definition. Oncogene. 2004; 23:2825-2837.

59. Teicher BA. Newer cytotoxic agents: attacking cancer broadly. Clinical cancer research. 2008; 14:1610-1617.

60. Su YF, Wu TF, Ko JL, Tsai HT, Tee YT, Chien MH, Chou $\mathrm{CH}$, Lin WL, Low HY, Chou MY, Yang SF and Wang $\mathrm{PH}$. The expression of ribonucleotide reductase M2 in the carcinogenesis of uterine cervix and its relationship with clinicopathological characteristics and prognosis of cancer patients. PloS one. 2014; 9:e91644.

61. Chang L, Guo R, Huang Q and Yen Y. Chromosomal instability triggered by Rrm $2 b$ loss leads to IL- 6 secretion and plasmacytic neoplasms. Cell reports. 2013; 3:13891397.

62. Lefort S, Joffre C, Kieffer Y, Givel AM, Bourachot B, Zago G, Bieche I, Dubois T, Meseure D, Vincent-Salomon A, Camonis $\mathrm{J}$ and Mechta-Grigoriou F. Inhibition of autophagy as a new means of improving chemotherapy efficiency in high-LC3B triple-negative breast cancers. Autophagy. 2014; 10:2122-2142. 
63. Ge J, Chen Z, Huang J, Chen J, Yuan W, Deng Z and Chen Z. Upregulation of autophagy-related gene-5 (ATG-5) is associated with chemoresistance in human gastric cancer. PloS one. 2014; 9:e110293. 